\title{
Thermotoga lettingae sp. nov., a novel thermophilic, methanol-degrading bacterium isolated from a thermophilic anaerobic reactor
}

\author{
${ }^{1}$ Laboratory of \\ Microbiology, Wageningen \\ University, Hesselink \\ van Suchtelenweg 4, \\ 6703 CT Wageningen, \\ The Netherlands \\ 2 Sub-Department of \\ Environmental \\ Technology, Wageningen \\ University, PO Box 8129, \\ 6700 EV Wageningen, \\ The Netherlands
}

\author{
Melike Balk, ${ }^{1}$ Jan Weijma ${ }^{2}$ and Alfons J. M. Stams ${ }^{1}$ \\ Author for correspondence: Melike Balk Tel: +31 317483739 . Fax: + 31317483829 . \\ e-mail:melike.balk@algemeen.micr.wag-ur.nl
}

\begin{abstract}
A novel, anaerobic, non-spore-forming, mobile, Gram-negative, thermophilic

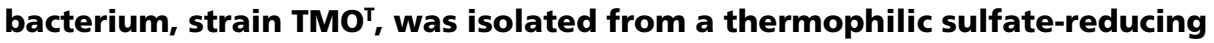
bioreactor operated at $65^{\circ} \mathrm{C}$ with methanol as the sole substrate. The $\mathrm{G}+\mathrm{C}$ content of the DNA of strain $\mathrm{TMO}^{\top}$ was $39.2 \mathrm{~mol} \%$. The optimum $\mathrm{pH}, \mathrm{NaCl}$ concentration, and temperature for growth were $7 \cdot 0,1.0 \%$, and $65^{\circ} \mathrm{C}$, respectively. Strain $\mathrm{TMO}^{\mathrm{T}}$ was able to degrade methanol to $\mathrm{CO}_{2}$ and $\mathrm{H}_{2}$ in syntrophic culture with Methanothermobacter thermautotrophicus $\Delta H$ or Thermodesulfovibrio yellowstonii. Thiosulfate, elemental sulfur, $\mathrm{Fe}(\mathrm{III})$ and anthraquinone-2,6-disulfonate were able to serve as electron acceptors during methanol degradation. In the presence of thiosulfate or elemental sulfur, methanol was converted to $\mathrm{CO}_{2}$ and partly to alanine. In pure culture, strain TMO' was also able to ferment methanol to acetate, $\mathrm{CO}_{2}$ and $\mathrm{H}_{2}$. However, this degradation occurred slower than in syntrophic cultures or in the presence of electron acceptors. Yeast extract was required for growth. Besides growing on methanol, strain $\mathrm{TMO}^{\top}$ grew by fermentation on a variety of carbohydrates including monomeric and oligomeric sugars, starch and xylan. Acetate, alanine, $\mathrm{CO}_{2}, \mathrm{H}_{2}$, and traces of ethanol, lactate and $\alpha$-aminobutyrate were produced during glucose fermentation. Comparison of 165 rDNA genes revealed that strain $\mathrm{TMO}^{\mathrm{T}}$ is related to Thermotoga subterranea (98\%) and Thermotoga elfii (98\%). The type strain is TMO' (= DSM 14385' $=$ ATCC BAA-301'). On the basis of the fact that these organisms differ physiologically from strain TMO'$^{\top}$, it is proposed that strain $\mathrm{TMO}^{\top}$ be classified as a new species, within the genus Thermotoga, as Thermotoga lettingae.
\end{abstract}

Keywords: Thermotoga lettingae sp. nov., thermophilic, syntrophic, methanol oxidation, thiosulfate reduction

\section{INTRODUCTION}

Methanol is formed during microbial pectin degradation and is released as a fungal biodegradation product of natural methoxylated aromatics, which are the building blocks of lignin (Donnelly \& Dagley, 1980; Schink \& Zeikus, 1980). Methanol is also known to be the main pollutant in evaporator condensates from the kraft pulping industry (Minami et al., 1986).

In anaerobic environments, methanol can be utilized by several groups of micro-organisms. In the presence

The GenBank/EMBL/DDBJ accession number for the 165 rDNA sequence of strain $\mathrm{TMO}^{\top}$ is AF355615. of $\mathrm{CO}_{2}$, homoacetogens are able to produce acetate and butyrate from methanol (Lettinga et al., 1979; Zeikus et al., 1980; van der Meijden et al., 1984). Methanol can be converted to $\mathrm{CO}_{2}$ either by sulfatereducing bacteria, which produce $\mathrm{H}_{2} \mathrm{~S}$ from sulfate (Braun \& Stolp, 1985; Nanninga \& Gottschal, 1986; Hattori et al., 2000), or by nitrate-reducing bacteria, which reduce nitrate to $\mathrm{N}_{2}$ (Bamforth \& Quayle, 1978; Urakami et al., 1995). Methanogens degrade methanol to methane and carbon dioxide (Schnellen, 1947; Sowers \& Ferry, 1983; Ollivier et al., 1984; Ni \& Boone, 1991). Methanol can also be degraded by syntrophic cultures of anaerobic micro-organisms (Heijthuijsen \& Hansen, 1986; Cord-Ruwisch \& Ollivier, 1986; Davidova \& Stams, 1996; Daniel et al., 
1999). However, none of these methanol-degrading micro-organisms is restricted to the use of methanol as a substrate.

Recently, the conversion of methanol in a thermophilic sulfate-reducing bioreactor was investigated by Weijma (2000). The bioreactor experiments indicated that a syntrophic type of conversion of methanol might play an important role. Therefore, we aimed to isolate the bacterium originating from the highest dilution series of the reactor sludge in methanolcontaining media. Here, we describe the isolation and characterization of a methanol-oxidizing bacterium, strain $\mathrm{TMO}^{\mathrm{T}}$, from the thermophilic methanoloxidizing consortium. Its morphological, physiological and phylogenetic characteristics are presented, and its taxonomic position is discussed.

\section{METHODS}

Sample source. Strain $\mathrm{TMO}^{\mathrm{T}}$ was isolated from a thermophilic $\left(65^{\circ} \mathrm{C}\right)$ sulfate-reducing and slightly saline $(0.7 \%$ $\mathrm{NaCl}$ ) bioreactor that was fed with methanol as the sole carbon and energy source, as previously described by Weijma (2000). From the reactor biomass a methanogenic enrichment culture was obtained with Methanothermobacter thermautotrophicus $\Delta \mathrm{H}$. M. thermautotrophicus $\Delta \mathrm{H}$ (= DSM 1053) was kindly provided by J. T. Keltjens (University of Nijmegen, The Netherlands). Thermodesulfovibrio yellowstonii (= DSM 11347), Thermotoga maritima (= DSM 3109), Thermotoga elfii (= DSM 9442), Thermotoga subterranea (= DSM 9912), Thermotoga thermarum (= DSM 5069), Thermotoga neapolitana (= DSM 4359) and Thermotoga hypogea (= DSM 11164) were obtained from the German Collection of Microorganisms and Cell Cultures (DSMZ, Braunschweig, Germany).

Culture media. The composition of the bicarbonate-buffered medium (MB) used for enrichment and routine growth experiments was based on medium 664 of the DSMZ (http://www.dsmz.de), with the following modifications: biotrypticase and sodium acetate were omitted and the amount of yeast extract was lowered to $0 \cdot 5 \mathrm{~g}^{-1}$. The $\mathrm{pH}$ was adjusted to $7 \cdot 0$ with $10 \mathrm{M} \mathrm{KOH}$ and the medium was boiled and cooled to room temperature under a stream of $\mathrm{O}_{2}$-free $\mathrm{N}_{2}$ gas. The medium was anaerobically dispensed into serum bottles under a $\mathrm{N}_{2} / \mathrm{CO}_{2}(80: 20, \mathrm{v} / \mathrm{v})$ gas atmosphere. The bottles were closed with butyl rubber stoppers sealed with crimp seals. The medium was autoclaved for $20 \mathrm{~min}$ at $121{ }^{\circ} \mathrm{C}$. Prior to inoculation, the medium was reduced with sterile stock solutions of $\mathrm{Na}_{2} \mathrm{~S} .7-9 \mathrm{H}_{2} \mathrm{O}$ and $\mathrm{NaHCO}_{3}$ to obtain final concentrations of 0.04 and $0.2 \%$, respectively. The pure culture of strain $\mathrm{TMO}^{\mathrm{T}}$ and the syntrophic culture with $M$. thermautotrophicus $\Delta \mathrm{H}$ were maintained by weekly transfer of a $10 \%(\mathrm{v} / \mathrm{v})$ inoculum to fresh medium. Bottles were incubated in the dark without shaking.

For isolation, the enriched syntrophic co-culture with $M$. thermautotrophicus $\Delta \mathrm{H}$ was incubated in the presence of methanol at $62{ }^{\circ} \mathrm{C}$ by using the soft-agar dilution method. Colonies which were visible after 3 weeks of incubation were picked with a sterile needle and subcultured in liquid medium containing $20 \mathrm{mM}$ of pyruvate (as a substrate) and bromoethanesulfonate (to inhibit methanogenesis). Serial agar and liquid dilutions in pyruvate-containing media were repeated until a pure culture was obtained.
Substrate-utilization tests. The ability of strain $\mathrm{TMO}^{\mathrm{T}}$ to metabolize soluble substrates was tested in MB medium. Substrates were added from sterile, anoxic, concentrated stock solutions to final concentrations of $20 \mathrm{mM}$, unless otherwise indicated. To test for electron acceptors, sodium thiosulfate $(20 \mathrm{mM})$, sodium sulfate $(20 \mathrm{mM})$, sodium nitrate $(20 \mathrm{mM})$, sodium sulfite $(5 \mathrm{mM})$, elemental sulfur $(2 \%$, $\mathrm{w} / \mathrm{v}), \quad \mathrm{Fe}(\mathrm{III}) \quad(10 \mathrm{mM})$, anthraquinone-2,6-disulfonate $(20 \mathrm{mM})$ and cystine $(10 \mathrm{mM})$ were added to the medium at the concentrations indicated.

For syntrophic growth on substrates, strain $\mathrm{TMO}^{\mathrm{T}}$ was inoculated in hydrogen-pregrown cultures of $M$. thermautotrophicus $\Delta \mathrm{H}$. Prior to inoculation, the gas phase of the bottles was changed to $\mathrm{N}_{2} / \mathrm{CO}_{2}(80: 20, \mathrm{v} / \mathrm{v})$, and substrates from sterile, concentrated stock solutions were added. Syntrophic growth of strain $\mathrm{TMO}^{\mathrm{T}}$ on methanol was also tested in co-culture with Thermodesulfovibrio yellowstonii in MB medium to which $20 \mathrm{mM}$ sulfate had been added. Yeast extract was not added to MB medium when syntrophic growth with $M$. thermantotrophicus $\Delta \mathrm{H}$ was being tested on methanol.

$\mathrm{pH}$, temperature, and sodium chloride concentration ranges for growth. The $\mathrm{pH}$, temperature, and $\mathrm{NaCl}$ concentration ranges for growth were determined in $\mathrm{MB}$ medium containing $1 \mathrm{~g}$ yeast extract $\mathrm{l}^{-1}$ and $5 \mathrm{~g}$ peptone $\mathrm{l}^{-1}$. The $\mathrm{pH}$ of the medium was adjusted by injecting calculated amounts of sterile $\mathrm{Na}_{2} \mathrm{CO}_{3}$ or $\mathrm{HCl}$ from the sterile, anaerobic stock solutions. To study the $\mathrm{NaCl}$ requirement, $\mathrm{NaCl}$ was weighed directly in the bottles before the medium was dispensed. Strain $\mathrm{TMO}^{\mathrm{T}}$ was subcultured at least once under the same experimental conditions before the growth rates were determined.

Light- and electron microscopy. Cell morphology and purity were examined with a phase-contrast microscope. Gram staining and motility were studied according to the standard procedure (Doetsch, 1981). Transmission electron microscopy was performed as described by Plugge et al. (2000).

Antibiotic susceptibility. Chloramphenicol, vancomycin, streptomycin, rifampicin or penicillin $\mathrm{G}$ from filter-sterilized stock solutions was added to a final concentration of $100 \mu \mathrm{g} \mathrm{ml}^{-1}$ to sterile, prereduced MB medium.

Analytical techniques. Most substrates were measured by HPLC, as described previously by Stams et al. (1993). Methanol was analysed by GC using a Chrompack gas chromatograph (model CP9000) equipped with a Sil5 CB column $(25 \mathrm{~m} \times 0.32 \mathrm{~mm})$ and a flame-ionization detector at $300{ }^{\circ} \mathrm{C}$. The column temperature was $50{ }^{\circ} \mathrm{C}$ and the injection port temperature was $250{ }^{\circ} \mathrm{C}$. The carrier gas was $\mathrm{N}_{2}$ saturated with formic acid. Amino acids were analysed by HPLC, as described by Kengen \& Stams (1994). Sulfide was determined as described by Trüper \& Schlegel (1964). Hydrogen and methane were determined quantitatively by GC (Stams et al., 1993). Thiosulfate was analysed by HPLC (Scholten \& Stams, 1995).

$\mathbf{G}+\mathbf{C}$ content. DNA was isolated and purified by the method of Marmur (1961). The $\mathrm{G}+\mathrm{C}$ content of the DNA was determined by thermal denaturation, as described by Owen et al. (1969).

$16 S$ rDNA sequence analysis. DNA was extracted as described by Zoetendal et al. (1998). PCR was performed with the bacterial primers $7 f$ and $1510 \mathrm{r}$ by using the Taq DNA polymerase kit from Life Technologies to amplify the 
bacterial 16S rDNA. The PCR products were purified with the Qiaquick PCR purification kit (Qiagen) according to the manufacturer's instructions. Primers 1100r, 519r, 530f, 342r (Lane, 1991), 803f (Stackebrandt \& Charfreitag, 1990) and 968f (Nübel et al., 1996), labelled with Infrared Dye 41 (MWG-Biotech), were used as sequencing primers. The sequences were automatically analysed on a LI-COR DNA 4000L sequencer and corrected manually. The sequences were checked for reading errors with the alignment programs of the ARB package (Strunk \& Ludwig, 1991). Homology searches of the ARB, EMBL and GenBank DNA databases for these partial sequences were performed with FASTA and the homologies were checked with the ARB programs.

DNA-DNA hybridization. DNA-DNA hybridizations were performed with strain $\mathrm{TMO}^{\mathrm{T}}$, Thermotoga elfii (= DSM 9442) and Thermotoga subterranea (= DSM 9912) at the Institute of Microbiology of the Russian Academy of Sciences in Moscow. DNA-DNA hybridization was performed by using the optical reassociation method as described by DeLey et al. (1970).

\section{RESULTS AND DISCUSSION}

\section{Enrichment and isolation}

Strain $\mathrm{TMO}^{\mathrm{T}}$ was enriched from a thermophilic anaerobic reactor described previously by Weijma (2000). The original co-culture was enriched without yeast extract. The strain was obtained first in co- culture with $M$. thermautotrophicus $\Delta \mathrm{H}$, using softagar media with methanol as the carbon and energy source. After 3 weeks incubation at $62^{\circ} \mathrm{C}$, colonies were about $1 \mathrm{~mm}$ in diameter, circular and opaque/ whitish. A single colony was picked and serially diluted in agar and liquid media containing $20 \mathrm{mM}$ pyruvate and $10 \mathrm{mM}$ bromoethanesulfonate. A pure culture of strain $\mathrm{TMO}^{\mathrm{T}}$ was used for further studies.

\section{Morphology}

Strain $\mathrm{TMO}^{\mathrm{T}}$ is a rod-shaped bacterium. The cells stained Gram-negative and were $0 \cdot 5-1 \times 2-3 \mu \mathrm{m}$, occurring singly or in pairs. Each cell was surrounded by a sheath-like structure that ballooned over the cell ends, and each had peritrichous flagella. The envelope was easily visible in all growth phases by phasecontrast microscopy. In the late stationary phase, the rods became spheres and were still surrounded by the sheath-like structures (Fig. 1). No endospores were observed in old cultures.

\section{Growth conditions}

Strain $\mathrm{TMO}^{\mathrm{T}}$ grew at temperatures ranging from 50 to $75^{\circ} \mathrm{C}$; optimum growth occurred at $65^{\circ} \mathrm{C}$, whereas no growth was observed at 45 or $80^{\circ} \mathrm{C}$. Growth was
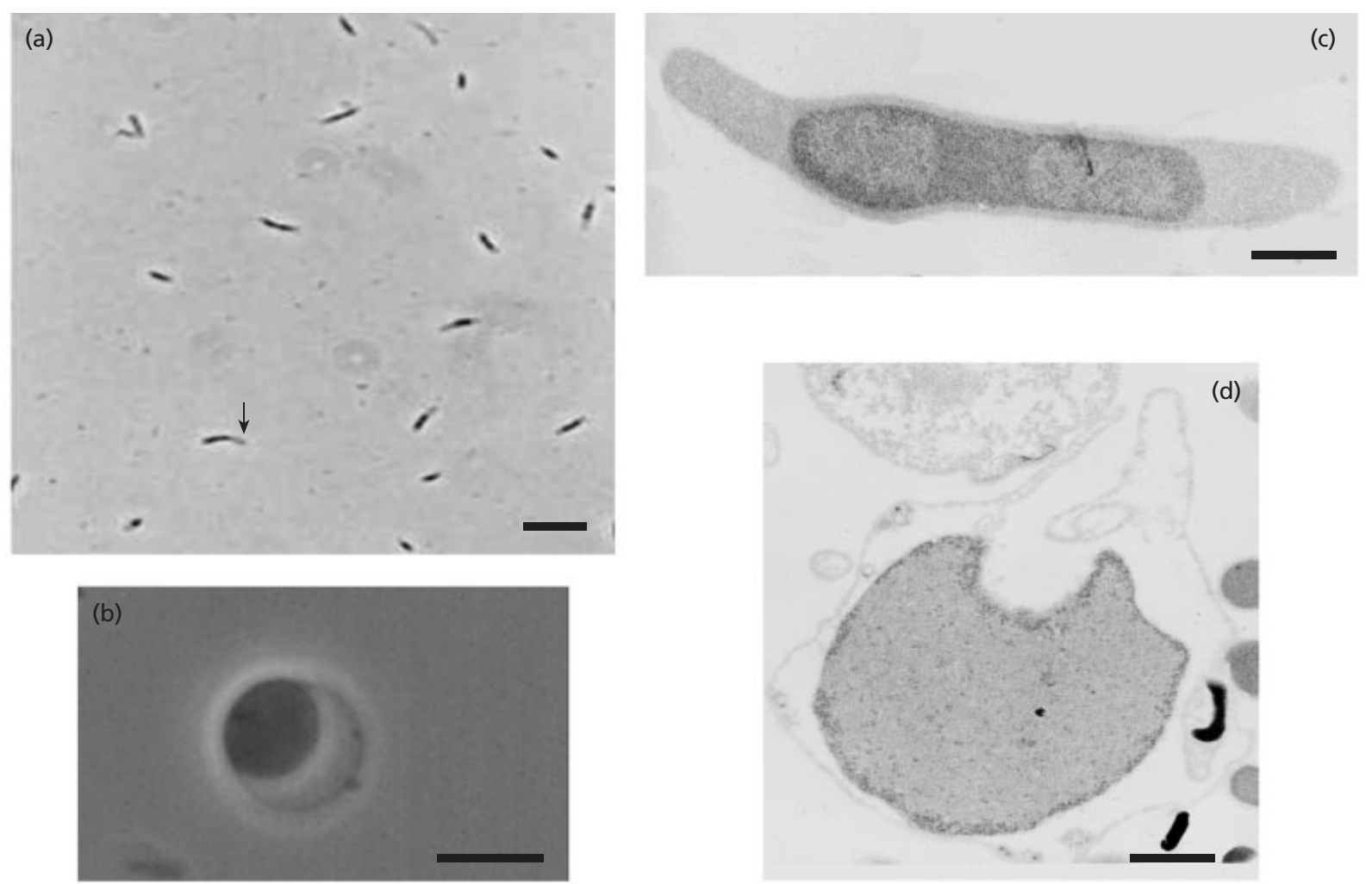

Fig. 1. $(a, b)$ Phase-contrast micrograph of strain $T M O^{\top}$, showing the toga (a, arrow) and a ballooning cell (b). Bars, $2.5 \mu \mathrm{m}$. (c, d) Electron micrographs of a thin section of strain $\mathrm{TMO}^{\top}$, showing the typical outer sheath-like structure (c) of the genus Thermotoga and a spherical cell (d) in stationary growth phase. Bars, $0.5 \mu \mathrm{m}$. 
(a)

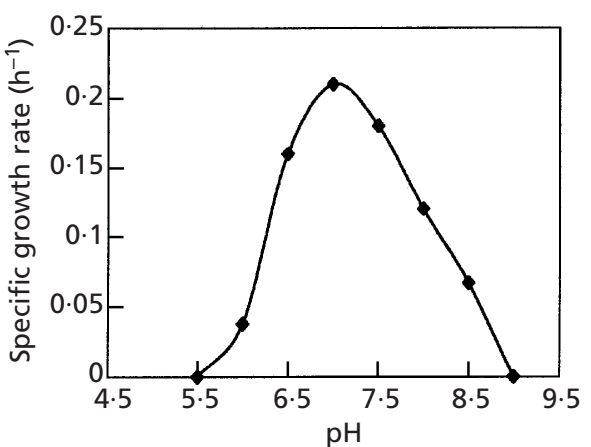

(b)

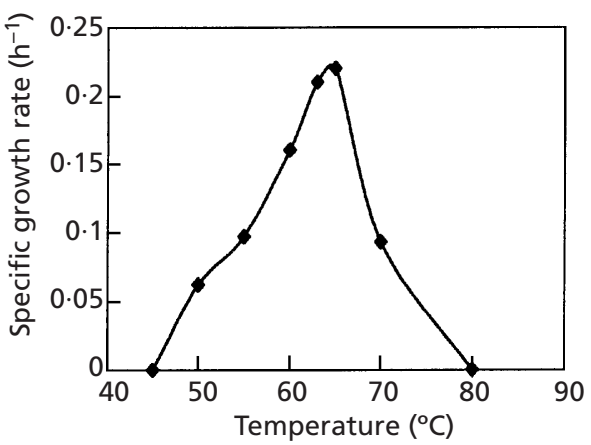

(c)

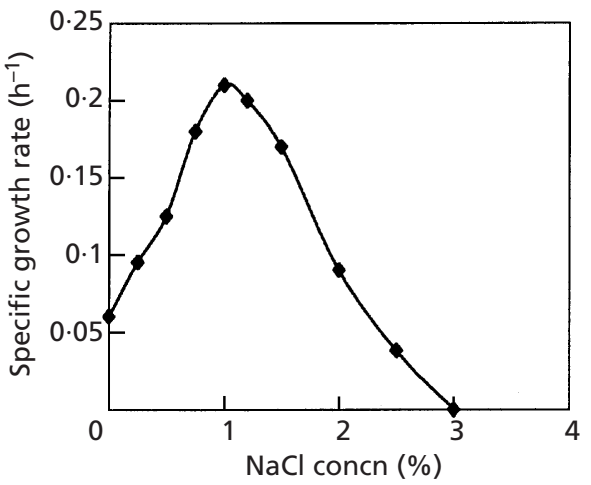

Fig. 2. Effect of $\mathrm{pH}$ (a), temperature (b) and $\mathrm{NaCl}$ concentration (c) on the growth of strain $\mathrm{TMO}^{\top}$ in $\mathrm{MB}$ medium. The specific growth rates were calculated from the slopes of the growth curves (not shown).

obtained between $\mathrm{pH} 6 \cdot 0$ and $\mathrm{pH} 8 \cdot 5$, optimum growth being at $\mathrm{pH} 7 \cdot 0$. The isolate grew in the presence of sodium chloride concentrations ranging from 0 to $28 \mathrm{~g} \mathrm{l}^{-1}$, the optimum being at $10 \mathrm{~g}^{-1}$ (Fig. 2). At the optimum temperature $\left(65^{\circ} \mathrm{C}\right), \mathrm{pH}(7 \cdot 0)$ and salinity $\left(10 \mathrm{~g} \mathrm{NaCl}^{-1}\right)$ for growth, the doubling time in the medium containing yeast extract and peptone was about $4 \mathrm{~h}$.

\section{Phylogeny, DNA base composition and DNA reassociation}

Using six primers, an almost complete sequence consisting of 1513 bases for the 16S rDNA gene of strain $\mathrm{TMO}^{\mathrm{T}}$ was obtained. On the basis of the

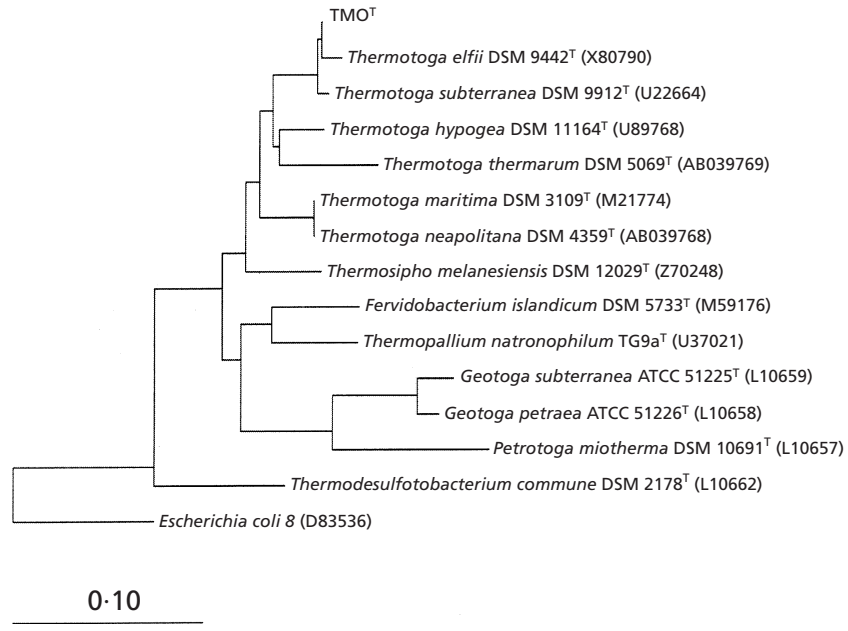

Fig. 3. Dendogram showing the position of strain $\mathrm{TMO}^{\top}$ among the members of the order Thermotogales and related bacteria. The bar represents an evolutionary distance of $0 \cdot 10$.

phylogenetic analysis (Fig. 3), strain $\mathrm{TMO}^{\mathrm{T}}$ appeared to be a member of the order Thermotogales, the closest relatives being Thermotoga subterranea (Jeanthon et al., 1995) and Thermotoga elfii (Ravot et al., 1995) (both $98 \%$ similarity).

Until now, representatives of the genus Thermotoga have not been isolated from a thermophilic anaerobic bioreactor (Huber et al., 1986; Jannasch et al., 1988; Windberger et al., 1989; Jeanthon et al., 1995; Ravot et al., 1995; Fardeau et al., 1997; Takahata et al., 2001). Furthermore, Thermotoga species were described as carbohydrate-fermenters that are able to utilize thiosulfate as an electron acceptor (Ravot et al., 1995).

Physiologically, strain $\mathrm{TMO}^{\mathrm{T}}$ differs from the species Thermotoga hypogea (Fardeau et al., 1997), Thermotoga maritima (Huber et al., 1986), Thermotoga neapolitana (Jannasch et al., 1988), Thermotoga thermarum (Windberger et al., 1989), Thermotoga petrophila and Thermotoga naphtophila (Takahata et al., 2001) by its lower optimal temperature, from the species Thermotoga maritima and Thermotoga neapolitana by its lower salinity range, but from the species Thermotoga hypogea and Thermotoga thermarum by its higher salinity range. Its physiological properties (temperature, $\mathrm{pH}$ optima and salinity requirement) are more similar to those of Thermotoga elfii and Thermotoga subterranea.

The DNA base composition $(\mathrm{G}+\mathrm{C})$ of strain $\mathrm{TMO}^{\mathrm{T}}$ was $39 \cdot 2 \mathrm{~mol} \%$, which is within the range reported for other Thermotoga species (Huber \& Stetter, 1992).

DNA-DNA hybridizations of strain $\mathrm{TMO}^{\mathrm{T}}$ with Thermotoga subterranea and Thermotoga elfii revealed 35 and $30 \%$ similarity, respectively. Although the results showed their low DNA homology, in the same 
Table 1. Methanol utilization of strain $\mathrm{TMO}^{\top}$ under different conditions

Duplicate cultures were incubated at $65^{\circ} \mathrm{C}$ until complete methanol degradation was measured.

\begin{tabular}{|c|c|c|c|c|c|c|c|}
\hline $\begin{array}{l}\text { Growth conditions for } \\
\text { strain } \mathrm{TMO}^{\mathrm{T}} \text { on methanol* }\end{array}$ & $\begin{array}{c}\text { Methanol } \\
\text { degraded } \\
(\mathbf{m M})\end{array}$ & $\begin{array}{c}\text { Acetate } \\
\text { formed } \\
(\mathbf{m M})\end{array}$ & $\begin{array}{c}\text { Alanine } \\
\text { formed } \\
(\mathbf{m M})\end{array}$ & $\begin{array}{c}\text { Sulfide } \\
\text { formed } \\
(\mathbf{m M})\end{array}$ & $\begin{array}{c}\mathrm{CH}_{4} \\
\text { formed } \\
\left(\mathrm{mmol} \mathrm{l}^{-1}\right)\end{array}$ & $\begin{array}{c}\text { Carbon } \\
\text { balance } \\
(\%) \dagger\end{array}$ & $\begin{array}{c}\text { Electron } \\
\text { balance } \\
(\%)+\end{array}$ \\
\hline- & $19 \cdot 7$ & $13 \cdot 7$ & - & - & - & 92 & 105 \\
\hline $\begin{array}{l}\text { In co-culture with } \\
\text { methanogen }\end{array}$ & $20 \cdot 7$ & - & - & - & $18 \cdot 2$ & 88 & 85 \\
\hline $\begin{array}{l}\text { In co-culture with } \\
\text { sulfate-reducer }\end{array}$ & $19 \cdot 2$ & - & - & $10 \cdot 2$ & - & 98 & 93 \\
\hline With thiosulfate & $18 \cdot 7$ & - & $5 \cdot 8$ & $11 \cdot 2$ & - & 93 & 120 \\
\hline With elemental sulfur & $10 \cdot 6$ & - & $3 \cdot 1$ & $7 \cdot 3$ & - & 87 & 120 \\
\hline
\end{tabular}

* In a pure culture of strain $\mathrm{TMO}^{\mathrm{T}}$, the yeast extract concentration was $0.5 \mathrm{~g} \mathrm{l}^{-1}$ in $\mathrm{MB}$ medium. Incubations were stopped when methanol was completely degraded.

$\uparrow$ Calculated to reduction of $\mathrm{CO}_{2}$ according to the energetics.

† Calculated as available hydrogen balance.

genus phylogenetically closely related bacteria $(99 \%$ similarity; Thermotoga neapolitana and Thermotoga maritima) also showed only $25 \%$ homology (Jannasch et al., 1988).

Growth of strain $\mathrm{TMO}^{\mathrm{T}}$ in $\mathrm{MB}$ medium containing glucose was inhibited by chloramphenicol and streptomycin but was not inhibited by rifampicin and penicillin $G$ (each at a final concentration of $100 \mu \mathrm{g} \mathrm{ml}^{-1}$ ). However, slight growth was observed with the same concentration of vancomycin.

\section{Growth on methanol}

Methanol utilization in a pure culture of strain $\mathrm{TMO}^{\mathrm{T}}$ was slow, and concomitantly low optical densities were obtained. Complete degradation of methanol occurred in around 30 days when $0.5 \mathrm{~g}$ yeast extract $1^{-1}$ was present (Table 1). Methanol degradation by a pure culture of strain $\mathrm{TMO}^{\mathrm{T}}$ did not occur when yeast extract was completely omitted.

Strain $\mathrm{TMO}^{\mathrm{T}}$ was able to convert methanol within 12 days in the presence of thiosulfate (Table 1). Similarly, in the presence of elemental sulfur, methanol was converted to alanine, $\mathrm{CO}_{2}$ and sulfide as end-products.

A remarkable characteristic of strain $\mathrm{TMO}^{\mathrm{T}}$ is its capacity to form alanine from methanol when thiosulfate or elemental sulfur is present. Although alanine formation from glucose metabolism has been reported for Pyrococcus furiosus (Kengen \& Stams, 1994), for a moderately thermophilic Clostridium species (Örlygsson et al., 1995) and for the order Thermotogales (Ravot et al., 1996), alanine formation from a $\mathrm{C}_{1}$ substrate has not been reported until now.

Growth of strain $\mathrm{TMO}^{\mathrm{T}}$ was also possible on methanol after inoculation into a hydrogen-pregrown culture of $M$. thermautotrophicus $\Delta \mathrm{H}$. Methanol was completely oxidized to $\mathrm{CO}_{2}$ in syntrophy with the methanogen

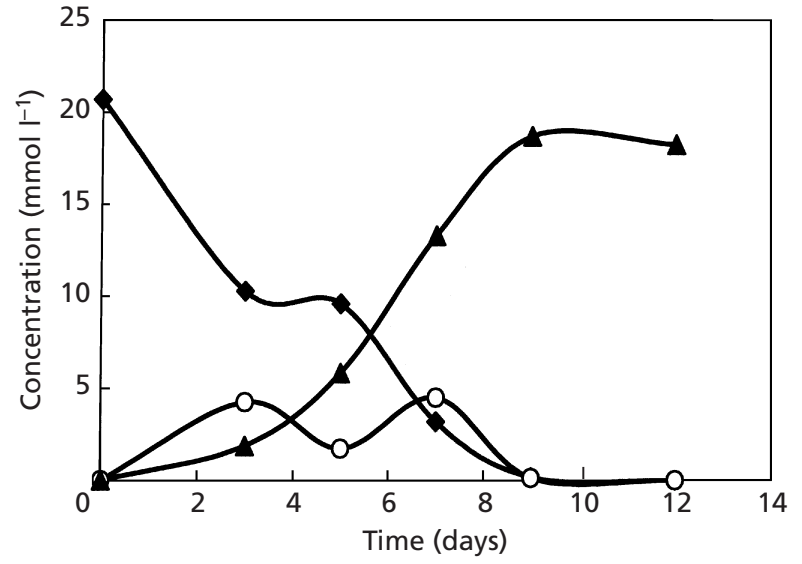

Fig. 4. Utilization of methanol $(\diamond)$ and production of acetate (O) and methane $(\boldsymbol{\Delta})$ by strain $\mathrm{TMO}^{\top}$ in co-culture with Methanothermobacter thermautotrophicus $\Delta \mathrm{H}$ in $\mathrm{MB}$ medium. The $\mathrm{pH}$ value, $\mathrm{NaCl}$ concentration, and temperature for growth were $7 \cdot 0,1.0 \%$, and $65^{\circ} \mathrm{C}$, respectively.

within 9 days (Fig. 4). Methanol oxidation also occurred when Thermodesulfovibrio yellowstonii was used in co-culture, where the products are $\mathrm{CO}_{2}$ and sulfide.

All of the Thermotoga species described to date require yeast extract for growth on carbohydrates. This suggests a requirement for certain growth factors. The fact that strain $\mathrm{TMO}^{\mathrm{T}}$ does not require yeast extract during syntrophic growth on methanol indicates that the methanogens provide these growth factors to strain $\mathrm{TMO}^{\mathrm{T}}$.

To our knowledge, the methanol-utilization capabilities of the Thermotoga species described to date have not been studied. We tested some Thermotoga species for their methanol-degradation abilities, and preliminary results indicated that Thermotoga subterranea, 
Table 2. Characteristics that differentiate strain $\mathrm{TMO}^{\top}$ from two close relatives, $T$. elfii DSM $9442^{\top}$ and T. subterranea DSM $9912^{\top}$

All Thermotoga species are characterized by the presence of outer sheaths, termed togas. Strain $\mathrm{TMO}^{\mathrm{T}}$ (= DSM 14385 ${ }^{\mathrm{T}}$ ), T. elfii DSM 9442 ${ }^{\mathrm{T}}$ and T. subterranea DSM $9912^{\mathrm{T}}$ are able to utilize glucose and reduce thiosulfate. Their salinity range is around $1 \%$. NR, Not reported.

\begin{tabular}{|lccc|}
\hline Characteristic & Strain TMO $^{\text {T }}$ & T. subterranea & T. elfii \\
\hline Source & Anaerobic bioreactor & Oil well, Paris & Oil well, Africa \\
Temp. range $\left({ }^{\circ} \mathrm{C}\right)$ & $50-70$ & $50-75$ & $50-72$ \\
Optimum temp. $\left({ }^{\circ} \mathrm{C}\right)$ & 65 & 70 & 66 \\
pH range & $6 \cdot 0-8 \cdot 5$ & $6 \cdot 0-8 \cdot 5$ & $5 \cdot 5-8 \cdot 7$ \\
Optimum pH & $7 \cdot 0$ & $7 \cdot 0$ & $7 \cdot 5$ \\
NaCl range $(\%)$ & $0-2 \cdot 8$ & $0-2 \cdot 4$ & $0-2 \cdot 4$ \\
Optimum NaCl conc. $(\%)$ & $1 \cdot 0$ & $1 \cdot 2$ & $1 \cdot 2$ \\
G+C content $($ mol $\%)$ & $39 \cdot 2$ & 40 & $39 \cdot 6$ \\
Reduction of S & + & - & - \\
Reduction of cystine & - & + & NR \\
Substrates used & + & NR & \\
Methanol & + & NR & NR \\
Pyruvate & + & NR & NR \\
Pectin & + & NR & NR \\
Cellobiose & + & NR & + \\
Xylose & + & NR & NR \\
Xylan & + & NR & NR \\
Starch & + & NR & NR \\
Methylamines & + & NR & - \\
Acetate + thiosulfate & + & NR & NR \\
Acetate in co-culture with & + & & \\
the methanogen & & & \\
\hline
\end{tabular}

Thermotoga elfi, Thermotoga thermarum and Thermotoga maritima are also able to grow on methanol. However, methanol oxidation by Thermotoga hypogea and Thermotoga neapolitana was hardly detectable.

\section{Growth on acetate}

Strain $\mathrm{TMO}^{\mathrm{T}}$ was able to grow on acetate in the presence of the methanogen or thiosulfate: $20 \mathrm{mM}$ acetate was converted to $\mathrm{CO}_{2}$ by strain $\mathrm{TMO}^{\mathrm{T}}$ in coculture with $M$. thermautotrophicus $\Delta \mathrm{H}$ in about 28 days when $0.5 \mathrm{~g}$ yeast extract $1^{-1}$ was present. As is the case for methanol conversion, strain $\mathrm{TMO}^{\mathrm{T}}$ converted $19 \mathrm{mM}$ acetate to $6 \mathrm{mM}$ alanine and $10 \mathrm{mM}$ sulfide when thiosulfate was present. In this case, acetate was converted within 36 days. Although slow growth of strain $\mathrm{TMO}^{\mathrm{T}}$ on acetate was observed, these results are in agreement with those for previously described acetate-degrading bacteria that are either thermophilic or mesophilic and coupled to a methanogenic partner or an electron acceptor (Zinder \& Koch, 1984; Schnürer et al., 1996; Hattori et al., 2000).

\section{Utilization of other substrates}

Growth was observed on complex substrates such as yeast extract, peptone, biotrypticase, gelatin or Casa- mino acids, and these complex substrates were fermented by strain $\mathrm{TMO}^{\mathrm{T}}$. Single substrates were tested in $\mathrm{MB}$ medium containing $0.5 \mathrm{~g}$ yeast extract $1^{-1}$. The following substrates were utilized in the absence or presence of the methanogen or thiosulfate: methanol, lactate, pyruvate, glucose, fructose, galactose (10 $\mathrm{mM})$, mannose (10 mM), xylose, lactose, maltose, sucrose $(10 \mathrm{mM})$, arabinose $(10 \mathrm{mM})$, ribose $(10 \mathrm{mM})$, cellobiose, rhamnose, glycerol, starch, xylan, pectin, methylamine, dimethylamine, trimethylamine, 2oxoglutarate and serine. Acetate, betaine, leucine, isoleucine and valine were utilized in the presence of the methanogen or thiosulfate. In the presence of thiosulfate, formate $(10 \mathrm{mM})$ and $\mathrm{H}_{2} / \mathrm{CO}_{2}(80: 20$, $\mathrm{v} / \mathrm{v}$ ) were also utilized for growth. The following substrates were tested, but not utilized, for growth in the absence or presence of the methanogen or thiosulfate: choline $(10 \mathrm{mM})$, benzoate $(10 \mathrm{mM})$, mannitol $(10 \mathrm{mM})$, butanol $(10 \mathrm{mM})$, isobutanol $(10 \mathrm{mM}), 2,3-$ butandiol $(10 \mathrm{mM})$, propanol $(10 \mathrm{mM})$, butyrate $(10 \mathrm{mM})$, succinate $(10 \mathrm{mM})$. Thiosulfate, elemental sulfur, $\mathrm{Fe}(\mathrm{III})$ and anthraquinone-2,6-disulfonate were able to serve as electron acceptors, unlike sulfate $(20 \mathrm{mM})$, sulfite $(5 \mathrm{mM})$, nitrate $(20 \mathrm{mM})$ and cystine $(10 \mathrm{mM})$ (Table 2). The presence of thiosulfate or elemental sulfur affected the pattern of fermentation products, as has been reported for Thermotoga hypogea (Fardeau et al., 1997). 
Strain $\mathrm{TMO}^{\mathrm{T}}$ was nutritionally versatile in its ability to use different sugars. During the sugar fermentation, acetate, alanine, $\mathrm{CO}_{2}, \mathrm{H}_{2}$, traces of ethanol, lactate and $\alpha$-aminobutyrate were produced. It is probable that $\alpha$ aminobutyrate is the unknown product that was found during glucose fermentation by Thermotoga maritima (Huber et al., 1986). The production of alanine and $\alpha$-aminobutyrate is a way of relieving hydrogen inhibition, as described previously for $P$. furiosus (Kengen \& Stams, 1994). In co-culture with the methanogen, strain $\mathrm{TMO}^{\mathrm{T}}$ degraded glucose to acetate and $\mathrm{CO}_{2}$. The other products were not detected.

The presence of thiosulfate had an effect on the alanine/acetate ratio produced during glucose fermentation. In the absence of thiosulfate, strain $\mathrm{TMO}^{\mathrm{T}}$ shifted its metabolism to alanine production; consequently, less acetate was produced. Depending on the growth conditions and the substrate used, the alanine concentration could be up to $13.4 \mathrm{mM}$.

Strain $\mathrm{TMO}^{\mathrm{T}}$ is also able to use elemental sulfur as an electron acceptor. In this respect, strain $\mathrm{TMO}^{\mathrm{T}}$ differs from the most closely related species, i.e. Thermotoga elfi $i$ and Thermotoga subterranea. Elemental sulfur can also be utilized as an electron acceptor by Thermotoga maritima and Thermotoga neapolitana during glucose fermentation. Moreover, in contrast to Thermotoga subterranea, strain $\mathrm{TMO}^{\mathrm{T}}$ is unable to utilize cystine as an electron acceptor. The other electron acceptors for methanol utilization by strain $\mathrm{TMO}^{\mathrm{T}}$ are $\mathrm{Fe}(\mathrm{III})$ and anthraquinone-2,6-disulfonate. The ability of hyperthermophilic micro-organisms, including Thermotoga maritima, to reduce humic substances and $\mathrm{Fe}(\mathrm{III})$ was reported by Lovley et al. (2000).

On the basis of genomic DNA-DNA hybridization and particular physiological differences (i.e. the ability to grow on $\mathrm{C}_{1}$ substrates and acetate and the ability to use elemental sulfur), we consider isolate $\mathrm{TMO}^{\mathrm{T}}$ to be a new species of the genus Thermotoga. We propose to name it Thermotoga lettingae.

\section{Description of Thermotoga lettingae sp. nov.}

Thermotoga lettingae (let'tin.gae. N.L. gen. n. lettingae of Lettinga, named after Gatze Lettinga, a Dutch biotechnologist, in recognition of his pioneering work on anaerobic methanol conversion in methanogenic bioreactors).

The cells are Gram-negative rods $2-3 \mu \mathrm{m}$ long $\times 0 \cdot 5-$ $1 \mu \mathrm{m}$ wide. Each rod is surrounded by a sheath-like structure, ballooning over the ends. Cells occur singly, in pairs or, rarely, in chains comprising a maximum of four rods. The rods tend to become large spheres in the stationary phase. Motile, strictly anaerobic, thermophilic. Growth occurs between 50 and $75^{\circ} \mathrm{C}$, the optimum being at $65^{\circ} \mathrm{C}$; between $\mathrm{pH} 6.0$ and $\mathrm{pH} 8.5$, the optimum being at $\mathrm{pH} 7 \cdot 0$; and at $\mathrm{NaCl}$ concentrations between 0 and $28 \mathrm{~g}^{-1}$, the optimum being at $10 \mathrm{~g} \mathrm{l}^{-1}$. The doubling time at optimum temperature and salinity at $\mathrm{pH} 7.0$ is $4 \mathrm{~h}$. Growth is possible on complex substrates such as yeast extract, peptone, gelatin, biotrypticase or Casamino acids. Uses thiosulfate, elemental sulfur, $\mathrm{Fe}(\mathrm{III})$ and anthraquinone2,6-disulfonate, but not sulfate, sulfite, nitrate or cystine, as electron acceptors. Grows on methanol, lactate, pyruvate, glucose, fructose, galactose, mannose, xylose, lactose, maltose, sucrose, arabinose, ribose, cellobiose, rhamnose, glycerol, pectin, methylamines, starch, xylan, 2-oxoglutarate and serine. In the presence of thiosulfate or a methanogen, it can grow on acetate, betaine, leucine, isoleucine and valine. In the presence of thiosulfate, it grows on formate and $\mathrm{H}_{2} / \mathrm{CO}_{2}$ but not on choline, benzoate, mannitol, butanol, isobutanol, 2,3-butandiol, propanol, butyrate or succinate. Methanol degradation occurs in syntrophic culture with Methanothermobacter thermautotrophicus $\Delta \mathrm{H}$ or Thermodesulfovibrio yellowstonii. Thiosulfate enhances the growth rate and substrate conversion. Isolated from an anaerobic bioreactor. The type strain is $\mathrm{TMO}^{\mathrm{T}}$, which has been deposited in the DSMZ as DSM $14385^{\mathrm{T}}$ and in the ATCC culture collection as BAA-301 ${ }^{\mathrm{T}}$.

\section{ACKNOWLEDGEMENTS}

The authors would like to thank A. Lysenko for determination of the $\mathrm{G}+\mathrm{C}$ content $(\mathrm{mol} \%)$ and for DNA-DNA hybridization analysis performed at the Institute of Microbiology of the Russian Academy of Sciences in Moscow, and C. M. Plugge for her help with the construction of the phylogenetic tree.

\section{REFERENCES}

Bamforth, C. W. \& Quayle, J. R. (1978). Aerobic and anaerobic growth of Paracoccus denitrificans on methanol. Arch Microbiol 119, 91-97.

Braun, M. \& Stolp, H. (1985). Degradation of methanol by a sulfate reducing bacterium. Arch Microbiol 142, 77-80.

Cord-Ruwisch, R. \& Ollivier, B. (1986). Interspecific hydrogen transfer during methanol degradation by Sporomusa acidovorans and hydrogenophilic anaerobes. Arch Microbiol 144, 163-165.

Daniel, R., Warnecke, F., Patekhina, J. S. \& Gottschalk, G. (1999). Identification of the syntrophic partners in a coculture coupling anaerobic methanol oxidation to Fe(III) reduction. FEMS Microbiol Lett 180, 197-203.

Davidova, I. A. \& Stams, A. J. M. (1996). Sulfate reduction with methanol by a thermophilic consortium obtained from a methanogenic reactor. Appl Microbiol Biotechnol 46, 297-302.

DeLey, J., Cattoir, H. \& Reynaerts, A. (1970). The quantitative measurement of DNA hybridization from renaturation rates. Eur $J$ Biochem 12, 133-142.

Doetsch, R. N. (1981). Determinative methods of light microscopy. In Manual of Methods for General Bacteriology, pp. 21-33. Edited by P. Gerhardt. Washington, DC: American Society for Microbiology.

Donnelly, M. I. \& Dagley, S. (1980). Production of methanol from aromatic acids by Pseudomonas putida. J Bacteriol 142, 916-924.

Fardeau, M.-L., Ollivier, B., Patel, B. K. C., Magot, M., Thomas, P., Rimbault, A., Rocchiccioli, F. \& Garcia, J.-L. (1997). Thermotoga hypogea sp. nov., a xylanolytic, thermophilic bacterium from an oilproducing well. Int J Syst Bacteriol 47, 1013-1019.

Hattori, S., Kamagata, Y., Hanada, S. \& Shoun, H. (2000). Thermoacetogenium phaeum gen. nov., sp. nov., a strictly anaerobic, thermophilic, syntrophic acetate oxidizing bacterium. Int J Syst Evol Microbiol 50, 1601-1609. 
Heijthuijsen, J. H. F. G. \& Hansen, T. A. (1986). Interspecies hydrogen transfer in co-cultures of methanol-utilizing acidogens and sulfate-reducing or methanogenic bacteria. FEMS Microbiol Ecol 38, $57-64$.

Huber, R. \& Stetter, K. O. (1992). The Thermotogales: hyperthermophilic and extremely thermophilic bacteria. In Thermophilic Bacteria, pp. 185-194. Edited by J. K. Kristjansson. London: CRC Press.

Huber, R., Langworthy, T. A., König, H., Thomm, M., Woese, C. R., Sleytr, U. B. \& Stetter, K. O. (1986). Thermotoga maritima sp. nov. represents a new genus of unique extremely thermophilic eubacteria growing up to $90^{\circ} \mathrm{C}$. Arch Microbiol 144, 324-333.

Jannasch, H. W., Huber, R., Belkin, S. \& Stetter, K. O. (1988). Thermotoga neapolitana sp. nov. of the extremely thermophilic eubacterial genus Thermotoga. Arch Microbiol 150, 103-104.

Jeanthon, C., Reysenbach, A.-L., L'Haridon, S., Gambacorta, A., Pace, N. R., Glenat, P. \& Prieur, D. (1995). Thermotoga subterranea $\mathrm{sp}$. nov., a new thermophilic bacterium isolated from a continental oil reservoir. Arch Microbiol 164, 91-97.

Kengen, S. W. M. \& Stams, A. J. M. (1994). Formation of L-alanine as a reduced end product in carbohydrate fermentation by the hyperthermophilic archaeon Pyrococcus furiosus. Arch Microbiol 161, 168-175.

Lane, D. J. (1991). 16S/23S rDNA sequencing. In Nucleic Acid Techniques in Bacterial Systematics, pp. 115-175. Edited by E. Stackebrandt \& M. Goodfellow. Chichester: Wiley.

Lettinga, G., van der Geest, A. T., Hobma, S. \& van der Laan, J. (1979). Anaerobic treatment of methanolic wastes. Water Res 13, 725-737.

Lovley, D. R., Kashefi, K., Vargas, M., Tor, J. M. \& Blunt-Harris, E. L. (2000). Reduction of humic substances and Fe(III) by hyperthermophilic microorganisms. Chem Geol 169, 289-298.

Marmur, J. (1961). Procedure for the isolation of deoxyribonucleic acid from microorganisms. J Mol Biol 3, 208-218.

Minami, K., Horiyama, T., Tasaki, M. \& Tanimoto, Y. (1986). Methane production using a bio-reactor packed with pumice stone on an evaporator condensate of a kraft pulp mill. J Ferment Technol 64, 523-532.

Nanninga, H. J. \& Gottschal, J. C. (1986). Isolation of a sulfatereducing bacterium growing with methanol. FEMS Microbiol Ecol $\mathbf{3 8}$, $125-130$.

Ni, S. \& Boone, D. R. (1991). Isolation and characterization of a dimethyl sulfide-degrading methanogen, Methanolobus siciliae HI 350, from an oil well, characterization of $M$. siciliae $\mathrm{T} 4 / \mathrm{M}^{\mathrm{T}}$, and emendation of M. siciliae. Int J Syst Bacteriol 41, 410-416.

Nübel, U., Engelen, B., Felske, A., Snaidr, J., Wieshuber, A., Amann, R. I., Ludwig, W. \& Bachhaus, H. (1996). Sequence heterogeneities of genes encoding 16S rRNAs in Paenibacillus polymyxa detected by temperature gradient gel electrophoresis. J Bacteriol 178, 5636-5643.

Ollivier, B., Lombardo, A. \& Garcia, J. L. (1984). Isolation and characterization of a new thermophilic Methanosarcina strain (strain MP). Ann Microbiol 135B, 187-198.

Örylgsson, J., Anderson, R. \& Svensson, B. H. (1995). Alanine as an end product during fermentation of monosaccharides by Clostridium strain P2. Antonie Leeuwenhoek 68, 273-280.

Owen, R. J., Hill, R. L. \& Lapage, S. P. (1969). Determination of DNA base composition from melting profiles in dilute buffers. Biopolymers $\mathbf{7}$, 503-516.

Plugge, C. M., Zoetendal, E. G. \& Stams, A. J. M. (2000). Caloramator coolhaasii sp. nov., a glutamate-degrading, moderately thermophilic anaerobe. Int J Syst Evol Microbiol 50, 1155-1162.

Ravot, G., Magot, M., Fardeau, M.-L., Patel, B. K. C., Prensier, G., Egan, A., Garcia, J.-L. \& Ollivier, B. (1995). Thermotoga elfii sp. nov., a novel thermophilic bacterium from an African oil-producing well. Int J Syst Bacteriol 45, 308-314.

Ravot, G., Ollivier, B., Fardeau, M.-L., Patel, B. K. C., Andrews, K. T., Magot, M. \& Garcia, J.-L. (1996). L-Alanine production from glucose fermentation by hyperthermophilic members of the domains Bacteria and Archaea: a remnant of an ancestral metabolism. Appl Environ Microbiol 62, 2657-2659.

Schink, B. \& Zeikus, J. G. (1980). Microbial methanol formation: a major end product of pectin metabolism. Curr Microbiol 4, 387-390.

Schnellen, C. G. T. P. (1947). Onderzoekingen over de methaangisting. PhD thesis, University of Delft.

Schnürer, A., Schink, B. \& Svensson, B. H. (1996). Clostridium ultunense sp. nov., a mesophilic bacterium oxidizing acetate in syntrophic association with a hydrogenotrophic methanogenic bacterium. Int J Syst Bacteriol 46, 1145-1152.

Scholten, J. C. M. \& Stams, A. J. M. (1995). The effect of sulfate and nitrate on methane formation in a freshwater sediment. Antonie Leeuwenhoek 68, 309-315.

Sowers, K. R. \& Ferry, J. G. (1983). Isolation and characterization of a methylotrophic marine methanogen, Methanococcoides methylutens gen. nov., sp. nov. Appl Environ Microbiol 45, 684-690.

Stackebrandt, E. \& Charfreitag, O. (1990). Partial 16S rRNA primary structure of five Actinomyces species: phylogenetic implications and development of an Actinomyces israelii-specific oligonucleotide probe. $J$ Gen Microbiol 136, 37-43.

Stams, A. J. M., van Dijk, J. B., Dijkema, C. \& Plugge, C. M. (1993). Growth of syntrophic propionate-oxidizing bacteria with fumarate in the absence of methanogenic bacteria. Appl Environ Microbiol 59, 1114-1119.

Strunk, O. \& Ludwig, W. (1991). ARB: a software environment for sequence data. Munich: Department of Microbiology, Technical University of Munich (e-mail: ARB@micro.biologie.tu-muenchen.de).

Takahata, Y., Nishijima, M., Hoaki, T. \& Maruyama, T. (2001). Thermotoga petrophila sp. nov. and Thermotoga naphthophila sp. nov., two hyperthermophilic bacteria from the Kubiki oil reservoir in Niigata, Japan. Int J Syst Evol Microbiol 51, 1901-1909.

Trüper, H. G. \& Schlegel, H. G. (1964). Sulphur metabolism in Thiorhodacea. I. Quantitative measurements of growing cells of Chromatium okenii. Antonie Leeuwenhoek 30, 225-238.

Urakami, T., Sasaki, J., Suzuki, K. I. \& Komagata, K. (1995). Characterization and description of Hyphomicrobium denitrificans sp. nov. Int J Syst Microbiol 45, 528-532.

van der Meijden, P., van der Drift, C. \& Vogels, G. D. (1984). Methanol conversion in Eubacterium limosum. Arch Microbiol 138, 360-364.

Weijma, J. (2000). Methanol as electron donor for thermophilic biological sulfate and sulfite reduction. $\mathrm{PhD}$ thesis, Wageningen Agricultural University.

Windberger, E., Huber, R., Trincone, A., Fricke, H. \& Stetter, K. O. (1989). Thermotoga thermarum sp. nov. and Thermotoga neapolitana occuring in African continental solfataric springs. Arch Microbiol 151, 506-512.

Zeikus, J. G., Lynd, L. H., Thompson, T. E., Krzycki, J. A., Weimer, P. J. \& Hegge, P. W. (1980). Isolation and characterization of a new, methylotrophic, acidogenic anaerobe, the Marburg strain. Curr Microbiol 3, 381-386.

Zinder, S. H. \& Koch, M. (1984). Non-acetoclastic methanogenesis from acetate: acetate oxidation by a thermophilic syntrophic coculture. Arch Microbiol 138, 263-272.

Zoetendal, E. G., Akkermans, A. D. L. \& de Vos, W. M. (1998). Temperature gradient gel electrophoresis from human fecal samples reveals stable and host-specific communities of bacteria. Appl Environ Microbiol 64, 3854-3859. 